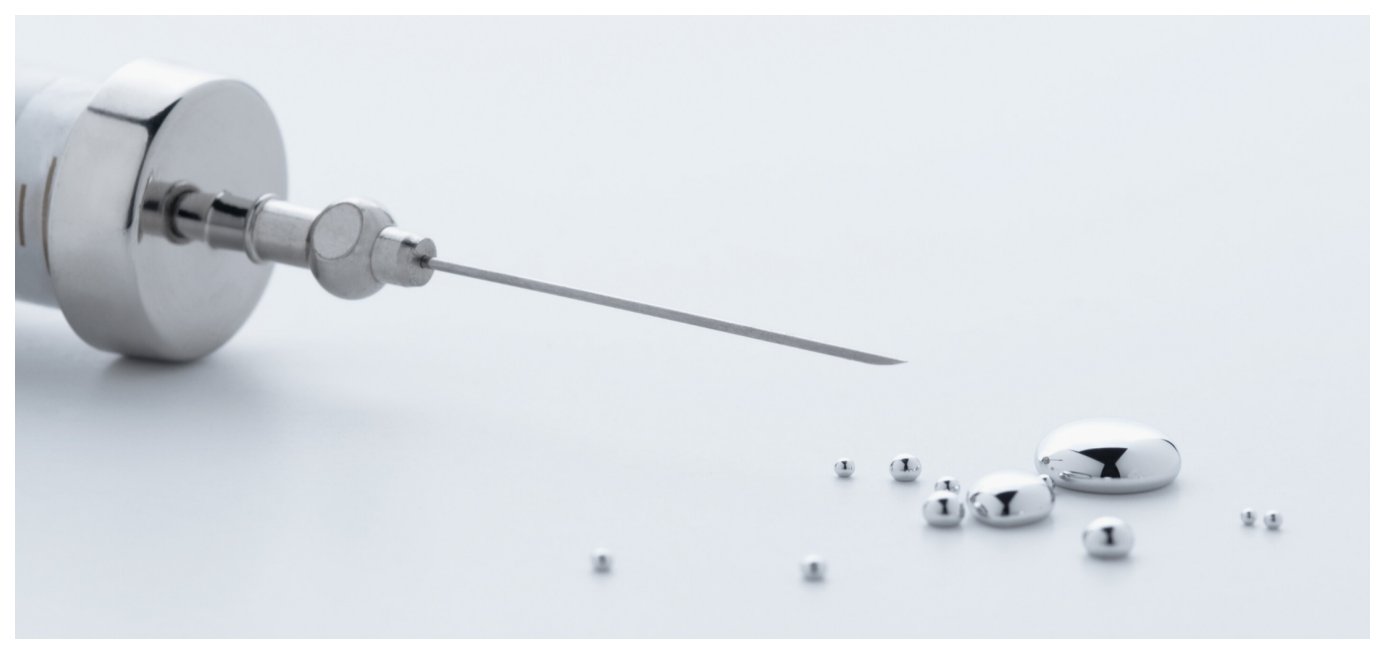

\title{
COVID-19 Heavy Metal Hypothesis
}

Tim X Lee

Funding: The author(s) received no specific funding for this work.

Potential competing interests: The author(s) declared that no potential competing interests exist.

\section{Abstract}

The bioaccumulation of heavy metals potentially makes certain individuals susceptible to COVID-19

A characterizing feature of coronavirus disease 2019 (COVID-19) is that the majority of people infected fight it off effectively with few or no symptoms presented. ${ }^{1-5}$ The typical immune response is more than sufficient to overcome the virus. There is however a small section of the population that is not able to do that and tragically succumb. There is something different about this subset of the population. We know conditions that increase your risk for succumbing to the virus are age, hypertension, obesity, and diabetes. ${ }^{6}$ Interestingly all of these conditions are also associated with the bioaccumulation of heavy metals. Seniors have significantly higher heavy metal levels in their blood than young people because each year you typically retain more than you excrete. ${ }^{7}$ Heavy metals increase risk for hypertension. ${ }^{8-12}$ Mercury causes hypertension by inactivating catecholaminei-0-methyl transferase, which increases serum and urinary epinephrine, norepinephrine, and dopamine. This effect increases blood pressure. ${ }^{8}$ This relationship is so well understood that Houston (2011) states "Mercury toxicity should be 
evaluated in any patient with hypertension." Heavy metals have a demonstrated association with diabetes and obesity as well. ${ }^{13-17}$ In addition, COVID-19 deaths appear to be related to the immune system launching a "cytokine storm" excessive levels of cytokines are released triggering a chain of events that can kill the patient. ${ }^{18}$ Mercury alters the cytokine response by increasing proinflammatory cytokines. Intriguingly, the relationship is even more specific than that, interleukin-1 $\beta$ (IL-1 $\beta$ ) cytokines are at the heart of COVID-19 induced cytokine storms, these are the exact cytokines that mercury increases. ${ }^{19-21}$ Endemen et al (2020) found that COVID-19 is linked to hypercoagulability. 22 This conclusion is supported by cohort studies that found hypercoagulability and a severe inflammatory state in COVID-19 patients. ${ }^{23,24}$ Hypercoagulability is one of the known effects of mercury. ${ }^{25-27}$ Viral infections activate the blood coagulation system. ${ }^{28}$ Coagulation stimulates the cytokine response and the expression of IL-1 $\beta$ genes. ${ }^{29,30}$ My hypothesis is that bioaccumulation of heavy metals is making certain individuals more susceptible to succumbing to COVID19. A hypothetical mechanism is illustrated in Figure 1. Mercury induced hypercoagulation is touched off by COVID-19 infection. Coagulation induces proinflammatory cytokine response exacerbated by mercury causing a cytokine storm.

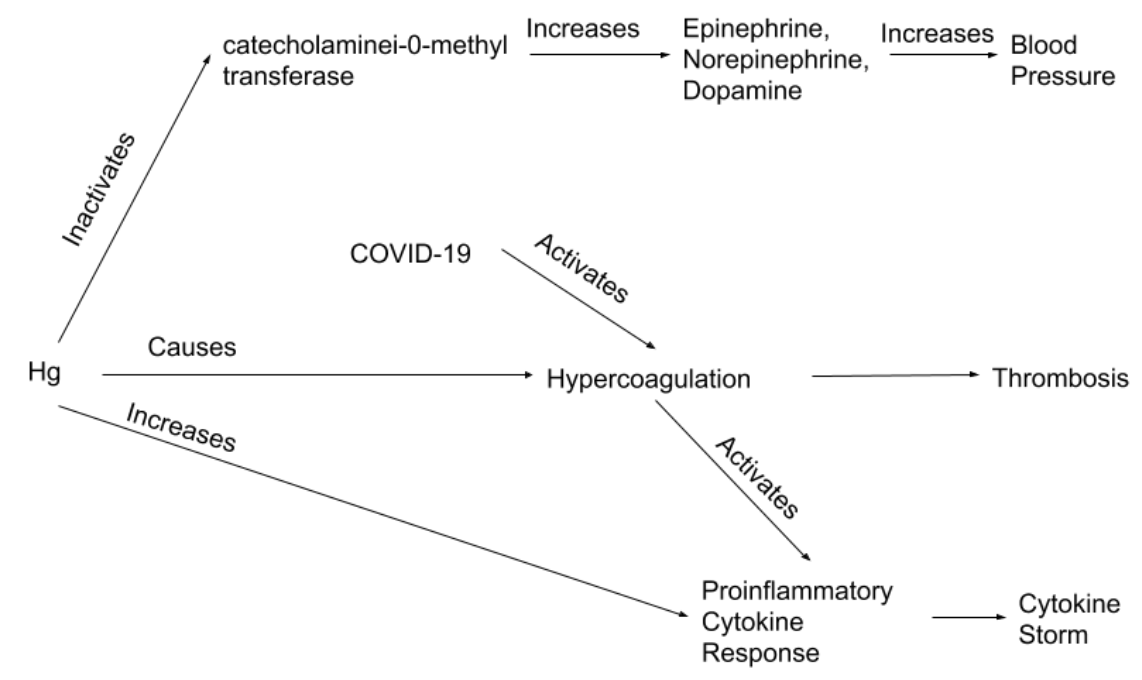

Figure1. Mercury $(\mathrm{Hg})$ causes hypertension by inactivating catecholaminei-0-methyl transferase. Mercury toxicity is known to cause hypercoagulation and a proinflammatory cytokine response as well. Illustrated is the hypothesized mechanism by which it is interacting with COVID-19 to lead to patient mortality. 
Lymphopenia, a below normal number of lymphocytes, has been of interest since the outset of the pandemic. ${ }^{31}$ Tan et al (2020) documented that lymphopenia predicts the severity of COVID-19 disease. ${ }^{32}$ Lymphopenia is associated with COVID-19 death and acute respiratory distress syndrome (ARDS). ${ }^{33}$ Gallais et al (2020) illustrate a mechanism for this effect as viral-specific T cell response is primary in fighting COVID-19 infection. ${ }^{5}$ Interestingly, methylmercury causes T cell death. ${ }^{34}$ Mercury is not the only heavy metal to interfere with immune function, arsenic and lead are also infamous for immunosuppresion. ${ }^{35-40}$

There are many sources of mercury contamination in our environment, mining, ag riculture, coal-fired power plants, municipal wastewater discharges to name a few. The San Francisco Bay is still contaminated with mercury from the gold rush that occurred in 1849. ${ }^{41}$ Seafood, rice, dental amalgams and skin lightening creams are a major source of mercury exposure in the United States. ${ }^{42-45}$ Since the consumption of those products varies widely between individuals the bioaccumulation of mercury also varies widely. That means certain individuals have very high levels of mercury relative to the rest of the population. Is it these individuals who are succumbing to infection with COVID-19?

Coronavirus are frequently innocuous, as is COVID-19 to the majority of people it infects. That opens the possibility that what we are seeing is not a new deadly strain of virus but a virus interacting with an acquired immune disorder. What may be different is not the lethality of the virus but the fact that it is new, highly contagious, spreading rapidly, thereby trigg ering an avalanche of fatalities amongst those with a heavy metal induced immune disorder.

Science creates falsifiable hypotheses. If heavy metals are making people susceptible to COVID-19, those with an adverse reaction, eg thrombosis and cytokine storm, should have higher levels of heavy metals than those who do not have an adverse reaction. This is an easily testable and falsifiable hypothesis. I'm proposing that we create a study to compare heavy metal levels in the two groups. The effects of mercury are consistent with the evidence so it is the most likely culprit.

If it turns out that heavy metals are causing a vulnerability to COVID-19 then we have gained an invaluable tool for identifying who is at risk and a method to proactively reduce risk. In addition to saving priceless human life, this discovery could save the world 
economy tens of trillions of dollars.

1. Baggett TP, Keyes H, Sporn N, Gaeta JM. Prevalence of SARS-CoV-2 Infection in Residents of a Large Homeless Shelter in Boston. JAMA. Published online April 27, 2020. doi:10.1001/jama.2020.6887

2. Baggett TP, Keyes H, Sporn N, Gaeta JM. COVID-19 outbreak at a large homeless shelter in Boston: Implications for universal testing. medRxiv. Published online April 15, 2020:2020.04.12.20059618. doi:10.1101/2020.04.12.20059618

3. Day M. Covid-19: four fifths of cases are asymptomatic, China figures indicate. BMJ. 2020;369. doi:10.1136/bmj.m1375

4. Mizumoto K, Kagaya K, Zarebski A, Chowell G. Estimating the asymptomatic proportion of coronavirus disease 2019 (COVID-19) cases on board the Diamond Princess cruise ship, Yokohama, Japan, 2020. Eurosurveillance. 2020;25(10):2000180. doi:10.2807/1560-7917.ES.2020.25.10.2000180

5. Gallais F, Velay A, Wendling M-J, et al. Intrafamilial Exposure to SARS-CoV-2 Induces Cellular Immune Response without Seroconversion. medRxiv. Published online June 22, 2020:2020.06.21.20132449. doi:10.1101/2020.06.21.20132449

6. Nearly All NYC-Area COVID-19 Hospitalizations Had Comorbidities. The Scientist Magazine ${ }^{\circledR}$. Accessed April 30, 2020. https://www.the-scientist.com/newsopinion/nearly-all-nyc-area-covid-19-hospitalizations-had-comorbidities-67476 7. Government of Canada SC. Lead, mercury and cadmium concentrations in Canadians, 2012 and 2013. Published July 15, 2015. Accessed April 30, 2020. https://www150.statcan.gc.ca/n1/pub/82-625-x/2015001/article/14209-eng.htm 8. Houston MC. Role of Mercury Toxicity in Hypertension, Cardiovascular Disease, and Stroke. J Clin Hypertens. 2011;13(8):621-627. doi:10.1111/j.1751-7176.2011.00489.x 9. Jaishankar M, Tseten T, Anbalagan N, Mathew BB, Beeregowda KN. Toxicity, mechanism and health effects of some heavy metals. Interdiscip T oxicol. 2014;7(2):6072. doi:10.2478/intox-2014-0009 10. Alghasham AA, Meki A-RMA, Ismail HAS. Association of Blood Lead level with Elevated Blood Pressure in Hypertensive Patients. Int J Health Sci. 2011;5(1):17-27. 11. Hu XF, Singh K, Chan HM. Mercury Exposure, Blood Pressure, and Hypertension: A Systematic Review and Dose-response Meta-analysis. Environ Health Perspect. 2018;126(7). doi:10.1289/EHP2863

12. Sørensen N, Murata K, Budtz-øørgensen E, Weihe P, Grandjean P. Prenatal 
Methylmercury Exposure as a Cardiovascular Risk Factor at Seven Years of Age.

Epidemiology. 1999;10(4):370-375.

13. Kolachi NF, Kazi TG, Afridi HI, et al. Status of toxic metals in biological samples of diabetic mothers and their neonates. Biol T race Elem Res. 2011;143(1):196-212. doi:10.1007/s12011-010-8879-7

14. Tsai T-L, Kuo C-C, Pan W-H, Wu T-N, Lin P, Wang S-L. Type 2 diabetes occurrence and mercury exposure - From the National Nutrition and Health Survey in Taiwan. Environ Int. 2019;126:260-267. doi:10.1016/j.envint.2019.02.038

15. Higher mercury levels in humans associated with increased risk for diabetes. ScienceDaily. Accessed April 30, 2020. https://www.sciencedaily.com/releases/2013/04/130407211547.htm 16. He K, Xun P, Liu K, Morris S, Reis J, Guallar E. Mercury exposure in young adulthood and incidence of diabetes later in life: the CARDIA T race Element Study. Diabetes Care. 2013;36(6):1584-1589. doi:10.2337/dc12-1842

17. Wang X, Mukherjee B, Park SK. Associations of cumulative exposure to heavy metal mixtures with obesity and its comorbidities among U.S. adults in NHANES 2003-2014. Environ Int. 2018;121(Pt 1):683-694. doi:10.1016/j.envint.2018.09.035

18. Jose RJ, Manuel A. COVID-19 cytokine storm: the interplay between inflammation and coagulation. Lancet Respir Med. 2020;0(0). doi:10.1016/S2213-2600(20)30216-2

19. Gardner RM, Nyland JF, Evans SL, et al. Mercury Induces an Unopposed Inflammatory Response in Human Peripheral Blood Mononuclear Cells in Vitro. Environ Health Perspect. 2009;117(12):1932-1938. doi:10.1289/ehp.0900855

20. Lubick N. IMMUNITY: Mercury Alters Immune System Response in Artisanal Gold Miners. Environ Health Perspect. 2010;118(6):A243.

21. Silva IA, Nyland JF, Gorman A, et al. Mercury exposure, malaria, and serum antinuclear/antinucleolar antibodies in amazon populations in Brazil: a cross-sectional study. Environ Health. 2004;3:11. doi:10.1186/1476-069X-3-11

22. Endeman H, Zee P van der, Genderen ME van, Akker JPC van den, Gommers D. Progressive respiratory failure in COVID-19: a hypothesis. Lancet Infect Dis. 2020;0(0). doi:10.1016/S1473-3099(20)30366-2

23. Panigada M, Bottino N, T agliabue $P$, et al. Hypercoagulability of COVID-19 patients in Intensive Care Unit. A Report of Thromboelastography Findings and other Parameters of Hemostasis. J Thromb Haemost JTH. Published online April 17, 2020.

doi:10.1111/jth.14850

24. Spiezia L, Boscolo A, Poletto F, et al. COVID-19-Related Severe Hypercoagulability in Patients Admitted to Intensive Care Unit for Acute Respiratory Failure. Thromb Haemost. Published online April 21, 2020. doi:10.1055/s-0040-1710018 
25. Worowski K. The Hypercoagulability in Mercury Chloride Intoxicated Dogs. Thromb Haemost. 1968;19(1/2):236-241. doi:10.1055/s-0038-1651201

26. Lim K-M, Kim S, Noh J-Y, et al. Low-Level Mercury Can Enhance Procoagulant Activity of Erythrocytes: A New Contributing Factor for Mercury-Related Thrombotic Disease. Environ Health Perspect. 2010;118(7):928-935. doi:10.1289/ehp.0901473

27. Song Y. [Effects of chronic mercury poisoning on blood coagulation and fibrinolysis systems]. Zhonghua Lao Dong Wei Sheng Zhi Ye Bing Za Zhi Zhonghua Laodong Weisheng Zhiyebing Zazhi Chin J Ind Hyg Occup Dis. 2005;23(6):405-407.

28. Antoniak S. The coagulation system in host defense. Res Pract Thromb Haemost. 2018;2(3):549-557. doi:10.1002/rth2.12109

29. Mileno MD, Margolis NH, Clark BD, Dinarello CA, Burke JF, Gelfand JA. Coagulation of whole blood stimulates interleukin-1 beta gene expression. J Infect Dis. 1995;172(1):308311. doi:10.1093/infdis/172.1.308

30. Poll T van der, Jonge E de, An H ten C. Cytokines as Regulators of Coagulation. Landes Bioscience; 2013. Accessed June 7, 2020.

https://www.ncbi.nlm.nih.gov/books/NBK6207/

31. Huang C, Wang Y, LiX, et al. Clinical features of patients infected with 2019 novel coronavirus in Wuhan, China. The Lancet. 2020;395(10223):497-506. doi:10.1016/S01406736(20)30183-5

32. Tan L, Wang Q, Zhang D, et al. Lymphopenia predicts disease severity of COVID-19: a descriptive and predictive study. Signal Transduct Target Ther. 2020;5(1):1-3. doi:10.1038/s41392-020-0148-4

33. Huang I, Pranata R. Lymphopenia in severe coronavirus disease-2019 (COVID-19): systematic review and meta-analysis. J Intensive Care. 2020;8(1):36. doi:10.1186/s40560020-00453-4

34. Shenker BJ, Guo TL, O I, Shapiro IM. Induction of apoptosis in human T-cells by methyl mercury: temporal relationship between mitochondrial dysfunction and loss of reductive reserve. Toxicol Appl Pharmacol. 1999;157(1):23-35. doi:10.1006/taap.1999.8652

35. Mishra KP, Rani R, Yadav VS, Naik S. Effect of lead exposure on lymphocyte subsets and activation markers. Immunopharmacol Immunotoxicol. 2010;32(3):446-449. doi:10.3109/08923970903503668

36. Soto-Peña GA, Luna AL, Acosta-Saavedra L, et al. Assessment of lymphocyte subpopulations and cytokine secretion in children exposed to arsenic. FASEB J. 2006;20(6):779-781. doi:10.1096/fj.05-4860fje

37. Vianna A dos S, Matos EP de, Jesus IM de, et al. Human exposure to mercury and its hematological effects: a systematic review. Cad Saúde Pública. 2019;35(2). 
doi:10.1590/0102-311x00091618

38. Oulhote Y, Shamim Z, Kielsen K, et al. Children's white blood cell counts in relation to developmental exposures to methylmercury and persistent organic pollutants. Reprod Toxicol. 2016;68. doi:10.1016/j.reprotox.2016.08.001

39. Gonsebatt ME, Vega L, Herrera LA, et al. Inorganic arsenic effects on human lymphocyte stimulation and proliferation. Mutat Res. 1992;283(2):91-95. doi:10.1016/0165-7992(92)90139-9

40. Burchiel SW, Lauer FT, Beswick EJ, et al. Differential susceptibility of human peripheral blood T cells to suppression by environmental levels of sodium arsenite and monomethylarsonous acid. PloS One. 2014;9(10):e109192. doi:10.1371/journal.pone.0109192 41. Mercury Contamination from Historical Gold Mining in California. Accessed April 30, 2020. https://pubs.usgs.gov/fs/2005/3014/

42. Xun P, Liu K, Morris JS, Jordan JM, He K. Distributions and determinants of mercury concentrations in toenails among American young adults: the CARDIA Trace Element Study. Environ Sci Pollut Res Int. 2013;20(3):1423-1430. doi:10.1007/s11356-012-1126-3 43. Parkin Kullmann JA, Pamphlett R. A Comparison of Mercury Exposure from Seafood Consumption and Dental Amalgam Fillings in People with and without Amyotrophic Lateral Sclerosis (ALS): An International Online Case-Control Study. Int J Environ Res Public Health. 2018;15(12). doi:10.3390/ijerph15122874

44. McKelvey W, Alex B, Chernov C, et al. Tracking Declines in Mercury Exposure in the New York City Adult Population, 2004-2014. J Urban Health Bull N Y Acad Med. 2018;95(6):813-825. doi:10.1007/s11524-018-0269-z 45. Bulka CM, Davis MA, Karagas MR, Ahsan H, Argos M. The Unintended Consequences of a Gluten-free Diet. Epidemiology. 2017;28(3):e24. doi:10.1097/EDE.0000000000000640 